\title{
American Political Discourse as Manifested in Hillary Clinton's Interviews: A Critical Approach
}

\author{
${ }^{1}$ Doha Mahmoud Abdel-Moety \\ ${ }^{1}$ Faculty of Education, Tanta University, Egypt \\ Correspondence: Abdel-Moety, Doha, Faculty of Education, Tanta University, Egypt. E-mail: \\ D.mahmoud@edu.tanta.edu.eg
}

Received: November 26, 2014

Accepted: December 11, 2014

Online Published: December 23, 2014

doi:10.5430/elr.v4n1p1

URL: http://dx.doi.org/10.5430/elr.v4n1p1

\begin{abstract}
The present study is concerned with American political discourse of interview genre. The study attempts an analysis of a number of TV interviews with the former Secretary of State Hillary Clinton. It adopts a critical discourse analysis approach that draws on work from different disciplines, namely, genre theory, systemic functional grammar, and critical discourse analysis. The study aims at achieving a number of goals. First, it attempts to explore some characteristics of American interview genre. Second, it aims at depicting features of Clinton's political discourse. Third, it tries to unravel the use of power through language. Fourth, it aims at exploring the hidden strategies that are involved in conveying ideological messages. Results of the study indicated that American interview genre as exemplified in Clinton's interviews incorporates some characteristics of casual conversations such as the use of fillers, informal or casual style, humor, vocatives, grammatical incompletion, ellipsis, and deixis. They also showed that Clinton's discourse has certain specific features. These features include the use of long, compound and complex sentences, the strategic and manipulative use of personal pronouns and modality features, and the use of combination of elements of political discourse with ordinary life and experience. In addition, results indicated the use of power in the interviews. Finally, the analysis revealed Clinton's political and ideological positions through the use of specific analytical categories. These categories include lexicalization, implication, authority, evidentiality, consensus example/illustration, distancing, polarization, and national self-glorification.
\end{abstract}

Keywords: Political discourse, Interview genre, Critical discourse analysis, Systemic functional grammar, Ideology

\section{Introduction}

Critical discourse analysis (CDA) has been of interest to many researchers in linguistics, language studies, and other social science disciplines in the past twenty years (Chouliaraki and Fairclough, 1999). This interest has led to a large number of studies analyzing oral and written texts particularly in the fields of politics and mass media. These studies have demonstrated how language, power and ideology are closely related. They have also shown that language use is far from being neutral. However, it has been observed that most of these studies have focused on written texts such as newspapers and institutional documents (Tracy, Inez-Guillem, Robles, and C'asteline, 2011). On the other hand, analyses of oral texts, particularly in American discourse, have concentrated mainly on political speech. Moreover, Wodak and Meyer (2009) have noticed that interactional texts such as dialogues have been rarely studied by CDA researchers. Thus, Wang (2010) calls for more attention to CDA studies since they can help explore the relationship between language, ideology, and power.

Therefore, the present study is concerned with investigating an aspect of discourse that has not received adequate attention within American discourse. It examines oral texts exemplified in TV political interviews with the former Secretary of State Hillary Clinton from a critical discourse analysis perspective. The study attempts an analysis that aims at a) exploring some characteristics of American interview genre; b) depicting features of Clinton's political discourse; c) unravelling the use of power through language; and d) exploring the hidden strategies involved in conveying ideological messages. 


\section{Literature Review}

\subsection{Critical discourse analysis}

Critical discourse analysis as an approach to language study can be traced back to classical antiquity (Stubbs, 1997). It is an interdisciplinary field that incorporates linguistic analysis, rhetorical analysis and social theory in order to relate language to its social context. It aims at showing "the relationship between discourse and society, text and context, and between language and power" (Henderson, 2005, p. 2). It focuses on revealing ways in which issues such as gender, ethnicity, cultural differences, ideology, and identity are constructed in discourse (Paltridge, 2013). In this sense, discourse is seen as a complex communicative event that ...embodies a social context, featuring participants (and their properties) as well as production and reception processes" (van Dijk, 1988, p. 2).

There are different theoretical approaches to CDA that use various methods such as systemic functional grammar, argumentative strategies, narrative analysis, and conversational analysis (Leeuwen, 2009). They differ, according to Fairclough and Wodak (1997, p. 262), in "how they see the mediation between the text and the social". Yet, they all agree on producing a "critical knowledge" that helps people "emancipate themselves from forms of domination through self-reflection" (Wodak and Meyer, 2009, p. 7). The most extensive work in CDA has been introduced by Norman Fairclough since 1989. In his approach to CDA, Fairclough (1995a) provides an extended definition for the term "discourse". For him, discourse includes different types of semiotic activity in addition to written and/or oral texts. He also views language as a social practice in which it is "socially shaped, but is also socially shaping - or socially constitutive" (p. 55). In other words, language use is constitutive of "social identities", "social relations", and "systems of knowledge".

Central to this view of language as a social practice are the concepts of power and ideology. Language is "a site of, and stake in, struggles for power" (Fairclough, 1989, p. 15). It is not "powerful on its own". Rather, "it gains power by the use powerful people make of it" (Wodak, 2011, p. 35). Thus, language and power are said to be related in two ways. These two ways include power acting in discourse and power acting behind discourse. Power in discourse is related to holders of power in social interactions and it has three dimensions. These dimensions, according to Zupnik (1991), are (1) control over relations between individuals, (2) power or control over the content, and (3) control over subjects. Power behind discourse, on the other hand, involves the effects of power, which show how orders of discourse are shaped and constituted. It is concerned with discourse as a hidden effect of power. It is evident in the differentiation of dialects into "standard" and "nonstandard" and in the conventions associated with a particular discourse type.

In this sense, the use of power through language has been discussed and studied from different perspectives. West and Zimmerman (1985), for example, provide the concept of participant identities that refer to three types of power, namely, master identities, situated identities, and discourse identities. Master identities include permanent factors such as age, sex, and social class. Situated identities refer to power related to social settings and discourse identities are the power created by the verbal activities of the participants.

Brody (1992), on the other hand, divides power into charismatic, social, and aesculapian. These kinds of power refer to the influence based on personal characteristics, social prestige, and professional knowledge consecutively.

However, it has been observed that the most relevant view of power to CDA is that of social power which is introduced as being based on privileged access to socially valued resources. These resources include wealth, income, position, status, force, group membership, education, and knowledge (van Dijk, 1993). In other words, power involves control of one member/group over other members/groups. This control, according to van Dijk (1993), pertains to action and cognition. That is, a powerful group may not only limit the freedom of action of others, but also influence their minds. So, for him, effective power is mostly cognitive and is mostly enacted by persuasion, dissimulation or manipulation, among other strategic ways to manipulate others according to one's own interests.

In this way, power is closely related to ideology, which is viewed as "meaning in the service of power" (Thompson (1984) as cited in Fairclough 1992, p. 14). Ideology is "a process [that] articulates together particular representations of reality, and particular constructions of identity, especially of the collective identities of groups and communities" (Fairclough and Wodak, 1997, p. 276). So, each text is said to include covert and hidden meanings that are manipulated for the interest of those who produce it. Moreover, each text is subject to multiple interpretations and "reading off" ideologies from it is not possible (Fairclough, 1995b). 


\subsection{Political discourse and media discourse}

The exercise of power and the use of ideology through language are quite evident in political discourse and media discourse. Consequently, these two types of discourse, which are characterized by hidden relations of power, are important within research on processes of social and cultural change (Fairclough, 1995b). Political discourse is defined as the talk of professional politicians or political institutions. Thus, political actions or practices are considered as discursive practices that have political functions and implications (van Dijk, 1997). Media discourse, on the other hand, is seen as having a signifying power in how language is used and in how things are represented in particular ways. Recent studies on American political and media discourse are summarized in the following paragraphs. These studies include Horváth (2009), Wang (2010), and Shayegh and Nabifar (2012).

Horváth (2009) conducted a CDA study that investigated the political speech of President Barak Obama. The study analyzed the strategies adopted by Obama in his public speech. Results of the study demonstrated that Obama's speech has some ideological components that draw on the concepts of "pragmatism, liberalism, inclusiveness, acceptance of religious and ethnic diversity and unity" (p.55). They also showed that Obama's employment of certain prominent words in his speech is an evidence of his "inclusive perception of the American society". Moreover, results showed that his choice of Biblical references is strategically intended to strengthen the notion of unity.

In another study, Wang (2010) analyzed the political discourse of Obama's public speech from a CDA perspective that draws on systemic functional approach. The analysis showed that Obama's language is simple and colloquial. Obama used simple words and short sentences to decrease the distance between him and his audience. He used first person pronouns and religious belief successfully to eliminate the distance between him and his audience. His speech is also characterized by the frequent use of "material processes". Finally, his choice of modals indicated a concern for making the audience follow and understand his political speech.

Shayegh and Nabifar (2012), on the other hand, studied ideological and socio-political relations of power in Obama's interviews. They adopted a CDA approach that is based on systemic functional grammar. Results of the study showed that Obama's discourse is characterized by: a) the use of simple words and short sentences; $b$ ) the use of material processes; c) the use of modality and transitivity; and d) the use of present simple and future simple tenses. Results also indicated that Obama used first person pronouns and religious terms strategically to shorten the distance between him and his audience. Moreover, results showed that Obama's power is manifested linguistically through the use of religion, persuasion, and future plan's statements.

These studies, it can be noted, concentrated on Obama's discourse as exemplified in his political speech and in his interviews. They did not focus on American discourse in general or on interview genre. So, the present study aims to fill this gap through focusing on characteristics of American interview genre and features of Clinton's discourse in addition to the strategic use of power and ideology.

\section{The present study}

The present qualitative study investigates American political discourse of interview genre. It attempts an analysis of a number of TV interviews with the former Secretary of State Hillary Clinton. It adopts a critical discourse analysis approach that integrates linguistic and social analyses of discourse aiming at revealing power relations and ideology.

\subsection{The data}

Five TV interviews with the former Secretary of State Hillary Clinton are selected for analysis. The choice of Hillary Clinton is due to a number of reasons. First, she is a well-known figure all over the world. Second, as Secretary of State, her political discourse can be considered representative of American political discourse. Third, previous analyses of her discourse were all conducted from a pragmatic approach rather than from a CDA approach. The interviews selected are homogeneous since they are all conducted in America. They all have a friendly and relaxed atmosphere. In addition, they all deal with similar political topics. To ensure that the data analyzed are representative of Mrs. Clinton, the researcher identified a period of three years for collecting the data. This period is from 2011 to 2013.Then, all TV interviews within this period were collected. The interviews which contain more than one interviewee such as those with both Mr. Obama and Mrs. Clinton, those which are conducted outside USA, and those in which the interviewer is non-American are excluded. Finally, five TV interviews are selected at random from the following web sites.

http://www.foxnews.com

http://abcnews.go.com

http://www.npr.org 
http://secretaryclinton.wordpress.com

http://www.cbsnews.com

\subsubsection{Introduction about Hillary Clinton}

Hillary Clinton is the former Secretary of State, a Democratic candidate, and "a proud" New Yorker. She has attracted the public's attention since her husband Bill Clinton was elected President in 1992. She is an experienced politician who ran for President in 2008 after serving as a Senator for New York State. Many politicians think that she will participate in the presidential campaign in 2016. She has specific views about a number of issues such as abortion, free trade, energy policy, environmental issues, foreign policy, war on terrorism, immigration, gun control, health care, tax issues, and gay rights.

\subsection{Framework of analysis}

The present study adopts an eclectic framework that draws on work from genre theory, systemic functional grammar, and CDA. These three approaches to language analysis are selected since they share common grounds in their analytical focuses. For example, Bhatia's (2002) three analytical perspectives used in the present study closely resemble those of Fairclough's (1989) CDA model, which in turn uses systemic functional grammar as a central part of analysis. Moreover, they are all based on the idea that "all linguistic forms express a particular stance" (Kress, 1990, p. 90), that each text is subject to multiple interpretations (Fairclough, 1995a), and that language represents the world in particular ways according to particular interests (Henderson, 2005). Hence, the present framework is selective. It aims to achieve the goals of the study and to avoid repetition of analytical points. The framework comprises the following points:

\subsubsection{Genre analysis}

The study applies Bhatia's (2002) analytical model of genre analysis that focuses on "investigating instances of conventionalized or institutionalized textual artifacts ... in order to understand how members of specific discourse communities construct, interpret and use these genres to achieve their community goals and why they write [or say] them the way they do" (Bhatia, 2002, p. 6). The model provides three complementary perspectives of discourse. These perspectives are the textual, the socio-cognitive, and the socio-critical.

The textual perspective views discourse as text. So, it is concerned with the analysis of language use with respect to formal and functional aspects of discourse. In the present study, this perspective will focus on grammatical and lexical features of spoken discourse.

The socio-cognitive perspective views discourse as genre. This means that it extends the analysis to context so that it accounts for how the text is used and exploited in specific contexts. It also accounts for how the text may be interpreted. Under this perspective, the feature of "intertextuality", "interdiscursivity", or "hyperidity" as presented by Fairclough (1992) will be examined. This feature refers to the presence of specific words of discourse mixed with the discourse of the speaker and/ or the combination in discourse of different genres. Fairclough $(1992$, p. 84) defines intertextuality as "the property texts have of being full of snatches of other texts, which may be explicitly demarcated or merged in, and which the text may assimilate, contradict, ironically echo, and so forth."

The socio-critical perspective views discourse as a social practice that focuses on the changing identities of the participants. To examine this perspective, the study will focus on reference through the use of personal pronouns.

\subsubsection{Systemic functional grammar}

The study draws on systemic functional grammar which relates language to its social context. Three types of grammatical analysis will be conducted. These types include transitivity analysis, modality analysis, and textual analysis.

According to Halliday (1985), there is a systematic correlation between context and language. Halliday and Matthiessen (2004) show that three different aspects of context correlate with the three different kinds of meaning expressed in language. The three determining context factors are the field of discourse, the tenor of discourse and the mode of discourse. The field of discourse refers to what is being talked or written about. The tenor of discourse means the relationship between the participants while the mood of discourse is concerned with whether the language is written or spoken. These three contextual dimensions are encoded into three types of meanings represented in language. These three types of meanings are: a) ideational meanings which are meanings about the world; $b$ ) interpersonal meanings which are meanings about roles and relationships; and c) textual meanings which are meanings about the message. Ideational, interpersonal, and textual meanings occur simultaneously in every clause or text to represent a function through grammatical and lexical choices. The ideational function consists mainly of 
transitivity and voice. Transitivity system includes six processes, namely, material process, mental process, relational process, behavioral process, verbal process and existential process. The interpersonal function is expressed through modality and mood and textual function refers to explicit and implicit meanings.

\subsubsection{Critical discourse analysis}

The study adopts Fairclough's (1989) critical model to study features such as persuasion, illusive speech and threat. The model consists of specific linguistic mechanisms that include persuasion, long turn taking, speaking illusively, and threat. In the present study, these mechanisms will be analyzed in relation to power and ideology.

\section{Analysis of the data and discussion of the results}

\subsection{General observations}

The examination of the data shows that the topics of the interviews are quite variant but they mostly focus on the following issues: a) US economy; b) US foreign policy in Iran, North Korea, Russia, Syria, Libya, Egypt, and Somalia; c) war on terrorism with reference to Bin Laden, Hamas, Hezbollah, and Al-Shabaab; d) Clinton's future plans with reference to her possible 2016 presidential campaign; and e) personal matters related to Clinton's health and family. The most common tense in the interviews is the present including present simple, present perfect and present continuous. Examples from the data include "I think", "we don't certainly condone", "I've received", "I've been around", and "we're raising with them". This common use of the present tense, according to Thornbury and Slade (2006), reflects the highly interpersonal function of spoken discourse. There are also instances of the use of past tense. Yet, this use is related to past events and/or narratives. Illustrative examples are "the president mentioned this in his speech", "we were quite concerned", "the Egyptian presidency repudiated them and reaffirmed", and "when I came into office". Clinton's language, in general, is not simple. Her sentences are long. Most of her sentences tend to be compound or complex rather than simple. The following extract illustrates one of the various uses of compound complex sentences which are found in the interviews:

McFadden: But there's never been a woman who's had a credible chance and it looks as if you might just be that person, and I know how serious you take commitment and obligation and how serious the women's issue is to you.

Clinton: Right, but I'm not making any commitments or obligations because I do take them seriously and I did an interview with President Obama the other night and obviously I know how important this is to the press, to journalists like yourself, but it's not what I'm thinking about.

This finding is different from Melamede's (1999) observation that Clinton "down[s] to earth simple language in her speeches and interviews" (p. 2).

\subsection{Characteristics of American interview genre}

According to genre analysis, the data belong to talk in one of the formal institutional settings. They are "semi-structured interviews" which have features that are different from informal day-to-day conversations. (Hutchby and Wooffitt, 1998). In these interviews, the interviewer asks a number of questions dealing with certain specific topics and at the same time s/he is at liberty to explore issues that may generate at the course of the interview. So, the format consists of chains of question-answer sequences in which the interviewer asks the questions and the interviewee provides the answers.

However, the analysis of the data shows that the interviews include a number of features that are typical of ordinary conversations. These features include the use of fillers, informal or casual style, humor, vocatives, grammatical incompletion, ellipsis, and deixis. The following sub section illustrates the use of these features in detail.

\subsubsection{Features of ordinary conversation}

The interviews analyzed reveal the use of fillers. This use of fillers is a common feature of ordinary conversation. It includes "pause fillers" such as "uh" and "um" and "verbal fillers" such as "well", "I mean", and "you know". These linguistic devices are used to fill a momentary hesitation and to buy time at the beginning of a speaking turn. In the following extract, both types of fillers are used by Clinton.

Clinton: Well, they're going to, uh, have to be given, uh, support from...

There is also informal or casual style in the interviews. This informal style contrasts with formal spoken genres. It is realized through lexical choices such as Clinton's use of the word "guys" in saying "these guys need to be stopped on the terrorism front" instead of the more formal word "people" or "men", her use of the informal verb "up" in saying 
"we have been upping the sanctions, and her use of "pick up" in saying "And I know that John Kerry will just pick up the ball and run with it.

In addition to this lexical choice, the analysis of the interviews reveals the use of humor which is considered a feature of ordinary conversation. This use of humor is intended, according to Tannen (1993), to maintain solidarity among speakers in conversations. An example of such use is found in the following extract from Clinton's answer to the interviewer's question about her future plans.

Couric: What are you going to do?

Clinton: Well, I don't know. I was thinking maybe take your job ...

Another common feature in the interviews analyzed is the use of vocatives. This use has the function of "adjusting or reinforcing the social relationship between the speaker and the addressee" (Biber et al., 1999, p. 1112). The analysis of the interviews reveals many instances for the use of vocatives by Clinton. This use of vocatives is not confined only to the beginning and end of the interviews but also in response to questions during the interviews. Examples of such usage are "But at the same time, Scott - and I want to ...", "Well, Michele, I think ...", and "yes, that's very good, Cynthia".

There are also instances of two types of grammatical incompletion in the interviews analyzed. The first type is caused by interruption as when Clinton interrupts the interviewer before finishing her question in the following extract:

\section{Van Susteren: Are you-}

Clinton: I'm absolutely great.

This finding is similar to that of Klanicová (2013) who remarks that Clinton always interrupts as a result of her high involvement. The second type is due to completion by the interviewer as in the following example:

Clinton: ... you know, when we found out about the plot to kill the, uh, ambassador from Saudi Arabia-

Van Susteren: Here in Washington

The analysis has also revealed the use of ellipsis, which refers to deliberate omission of items such as subject pronouns and verb complements. This feature is seen in ellipted questions such as "you Ok?" in which the verb is omitted and "Why?" in which both subject pronoun and verb complement are omitted.

Finally, the analysis has shown instances of direct reference to features of the immediate situation through the use of deixis or deictic expressions. These instances include spatial deixis, temporal deixis and personal deixis. The interviews analyzed include spatial deixis such as demonstratives, temporal deixis such as "here" and "now", and personal deixis such as personal pronouns. The following example illustrates one of these usages.

Clinton: sitting here right now, that is certainly what I believe

Thus, the existence of these linguistic features, which Thornbury and Slade (2006) identify as characteristics of casual conversation, indicates the intertextual properties of American TV interviews. These properties are manifested in a mixture of the genre of interview and that of spontaneous conversation. This mix of genre, which Fairclough (1995b) refers to as hybridity, is called conversationalization. It is realized in a variety of linguistic features which are evident in the interviews. Most obvious are fillers, items of colloquial vocabulary, grammatical incompletion, ellipses, and deixis. Conversationalization is a feature of "contemporary social life" and it characterizes modern media discourse in general. So, it is not confined only to American TV interviews. This finding is in line with Cap and Okulska (2013) who states that modern interviews reveal a new evolving hybrid structure.

\subsection{Features of Clinton's political discourse}

In order to depict features of Clinton's political discourse, the analysis focuses on investigating the way Clinton uses language in the interviews. This use is exemplified in the use of different discourse types, the strategic use of personal pronouns, the use of modality features, and the use of implicit meaning. First, the analysis shows that Clinton combines different discourses together by adding personal experience to political issues. The data includes various examples in which there are elements of political discourse together with ordinary life and ordinary experience. This new combination gives Clinton's discourse a populist quality. For example, in talking about America's foreign policy in Iran, Clinton referred to her personal experience saying "when I came into office, there were too many countries that were turning a blind eye to it" and in another interview, she refers to America's current state by saying "That was not how America was viewed when I took this office". This finding is similar to that of Fairclough and Wodak (1997) in relation to Thatcher's discourse which is characterized by hybridizing the political 
orders of discourse with orders of discourse of ordinary life. It is also in line with Klanicová (2013) who states that Clinton "always" adds her personal experience in interviews. The same result has been observed by Fisker (2009) who notices that Clinton's discourse is characterized by proficient use of the phenomena of intertextuality.

Second, the analysis indicates that there are various examples for the constitution of personal identities through the strategic and manipulative use of personal pronouns, particularly the distribution of "I" and "we". It has been noticed that Clinton's answers to questions are sometimes given from an individual "I"- perspective and sometimes from a collective "we"- perspective. This use presents Clinton in certain roles by making "I" or "we" the subject of particular verbs which belong to semantic fields associated with feeling, speaking, and action. In the data analyzed, "I" was used as a subject of a large number of verbs such as "think", "believe", "hope", "want", "said", "went", "received", "negotiated", and "worked". These usages position Clinton as a truthful narrator, on the one hand, and as a woman of action, on the other hand. Illustrative examples from the interviews include Clinton's saying "I think that post the Arab revolutions... there was always going to be a period of adjustment", and "I hammered out an agreement in Geneva last summer ....". As for the use of the pronoun "we", the analysis shows that there are vague and shifting meanings of it in Clinton's talk. There are various examples for the use of inclusive we and exclusive we. "We" is sometimes used as inclusive to refer to both audience and general population as when Clinton says "we were going to once again assume a leadership position that was in concert with our values", and sometimes as exclusive to refer only to Administration as in saying "And we also wanted to make it clear that, ..., President Assad of Syria can either lead this transition or get out of the way". In other cases, "we" may be taken as either. For example, in one of the interviews, Clinton says "we have security interests, we have economic interests, and we have interests that affect our values". In this example, "we" may be understood as exclusive referring to the Administration or as inclusive referring to Clinton, the Administration, the audience and the general population. This finding is in line with Fairclough and Wodak's (1997) observation about Thatcher's use of personal pronouns. Moreover, it agrees with Melamede (1999) who states that Clinton's use of inclusive "we" is strategic. It is meant to connect her with her audience and to make her discourse more socially accepted.

Third, the analysis of modality features shows that Clinton's discourse in the interviews includes a large number of strong obligational and epistemic modalities which are realized through the use of modals, adverbs, and verbs. Modals are exemplified in the use of "must, should, have to, need to, and had to". Adverbs include "certainly, and absolutely". Verbs are found in "think, believe, and wish". Moreover, the analysis shows that these modality features are always concerned with foreign policy and war on terrorism. In the following extract, for instance, Clinton used the modal "have to" and the verb "think" when she was asked about foreign policy in Russia saying, "I think we have to make it clear that there are certain actions and policies that the United States will pursue because they are in our interest". Similarly, when she was asked about the killing of Usama bin Ladin she said "I certainly wouldn't go into any operational details". These modality features, as Halliday (1985) remarks, are significant techniques for expressing argument and opinion since they allow the speaker to express ideas with certain degrees of certainty and to present judgments and attitudes toward what he/she commits himself/herself to. So, this usage in the interviews analyzed can be seen as constituting a strong identity for Clinton. This identity is gained through her position and through US authority. In addition, it can be interpreted as a means for powerfully claiming political authority. This finding about the use of modalities agrees with that of Aisyah (2012) who observes that the use of modal verbs and evaluation in Clinton's discourse is strategic. It also agrees with that of Klanicová (2013) who asserts that Clinton's statements are always strong, confident and emphatic.

Fourth, the analysis shows that Clinton uses both explicit and implicit meanings in the interviews. For instance, when Clinton was asked about foreign policy in Iran, she explicitly answered:

Clinton: Well, as you know, our policy is prevention, not containment. And we have through the hard work we've undertaken with the international community, uh, imposed the toughest set of sanctions, international and bilateral. We know it's having an effect.

Yet, in the following example Clinton uses implicit meaning to let her audience infer that what the Iranians say does not conform to what they do.

Van Susteren: You don't believe that.

Clinton: Well, you know, I'm from the trust-but-verify camp when it comes to Iran. You know, this is what they say. They continue to say it. But we have a body of evidence that points in the other direction. I mean if that is true, then why are they developing a missile program that has intercontinental ballistic capacity? You know, why are they adding centrifuges and more enrich uranium as a result? 
This finding about the use of implicit meaning in Clinton's discourse is similar to that of Aisyah (2012) who observes that Clinton uses this technique in her speech in order to deliver her thoughts without being realized by the audience.

\subsection{The use of power}

The analysis shows that Clinton's power in the interviews is manifested through the strategic use of language which allows her to control information, to position herself and others in specific relationships, and to make assumptions about realities. First, the analysis of transitivity indicates that Clinton's discourse included all the six processes identified by Halliday (1985), namely, material processes, mental processes, relational processes, verbal processes, behavioral processes, and existential processes. The following are illustrative examples for the use of these processes in Clinton's discourse.

Clinton: And we produced evidence. (material process)

Clinton: I don't think it has to be any particular person ... (mental process)

Clinton: We have been very productive players in trying to deal with an extremely complex problem. (relational process- identifying)

Clinton: There is nothing fast or easy about diplomacy. (relational process -attributive)

Clinton: I said that the first time I went to Pakistan. (verbal process)

Clinton: (laughs) I hope I get to sleep in (laughing) (behavioral process)

Clinton: ..., there was disbelief on the part of a lot of countries. (existential process)

Yet, it has been observed that the choice of material, mental and relational processes is strategic. These processes are always employed with reference to power. This strategic use is evident in using material process with different kinds of speech acts related to action and decision-taking together with first person singular pronoun and/or modals. For instance, in the following example Clinton responds to a question about how she thinks about her place in history by using material process and first person singular pronoun. This choice positions her as a woman of action.

Clinton: I've worked on all of these because I wanted to be sure that the United States was at the table looking for a way of structuring the legal international frameworks that are going to have to be put into place.

In the following example, on the other hand, she uses material process together with the modal must when talking about Obama doctrine as regards foreign policy. This choice may be interpreted as an indication of power. This finding is in line with that of Myhill (1995) who asserts that must is always associated with power.

Clinton: The United States must tell its story better, must connect with young people better, must stand for our values more strongly.

Similarly, the choice of relational and mental processes views Clinton in the interviews as a truthful narrator and helps her persuade her audiences of what she says. The following example illustrates one of such usages of relational and mental processes in talking about what she hopes her "lasting legacy will be"

Clinton: I think the last four years have been ultimately quite important for the United States to demonstrate that we were going to once again assume a leadership position that was in concert with our values.

Second, the analysis shows that Clinton's power is also manifested in her comments on the interviewers' questions before answering them, on the one hand, and in her use of "rhetorical persuasion", on the other hand. Examples of Clinton's comments are found in response to a question about Egypt, in particular, the interviewer said "your thoughts on what's going to happen? What should we do, if anything? And what does it mean for the region?" Clinton comments before answering by saying: "Well, those are three really important questions." And in the following example when the interviewer said" I'd like to turn to Syria because your critics describe Syria as this administration's Rwanda. And I wonder how it weighs on you and what more the U.S. could have done to prevent the deaths of now 60,000 people", she said "Well, it's not a historically accurate analogy".

Rhetorical persuasion, on the other hand, is achieved through the use of rhetorical questions, listing, contrastive devices, and extreme case formulations which Clinton effectively employed to achieve power in discourse. There are various examples in the interviews to demonstrate this usage. For example, when asked about what she could pass to John Kerry, Clinton uses a rhetorical question:

I've tried to pass on everything I've learned. ... Condi Rice travelled a million miles and I travelled nearly that and went to more countries than anybody has gone and why do we do that? 
Because we are gluttons for punishment? No, because the United States has to show up.

Similarly, the interviews include a large number of listing. For instance, when asked "Why does the killing of civilians in Libya justify U.S. military involvement, but the killing of civilians in Syria does not? Clinton uses listing saying:

Clinton: Now, I think it's very important that, as President Obama has said and repeated again today, we have real interests as the United States. We have security interests, we have economic interests, and we have interests that affect our values, because we do believe in democracy and what it can bring to people.

This strategic use of rhetorical questions and listing is very effective. It strengthens and affirms Clinton's position and argument.

Another technique that Clinton uses is contrastive devices. In this technique, one argument or approach is contrasted with another in such a way that the speaker's favored position is seen superior. Clinton uses contrastive device to positively evaluate her stance and at the same time criticize other positions. This usage is evident in the following example when asked about Benghazi and how "it seemed as though [she] lost [her] temper at the hearing momentarily the other day", she said:

Clinton: ... when they focus not on the fact that we had such a terrible event happening with four dead Americans but instead with what did somebody say on a Sunday morning talk show, that to me is not in keeping with the seriousness of the issue and the obligation we all have as public servants.

Power is also achieved through the use of what is called extreme case formulations which are referred to by Hutchby and Wooffitt (1998) as a means to warrant claims. These extreme case formulations are simply ways of referring to "an object or event which invokes its maximal or minimal properties" (p. 209). Examples of these usages are common in the interviews. They include "never", "always", "no one", "nobody", "everyone", "certainly", "extremely", and "absolutely". In the following example, Clinton uses this technique in reference to North Korea and Iran when she says "Nobody is satisfied with what these two countries are attempting to do."

The analysis has also shown Clinton's use of specific linguistic mechanisms that are closely related to power. The mechanisms used in the interviews include long turn-taking, and threat. Long turn taking is found particularly in her talk related to foreign policy and terrorism. Threat is also used in relation to foreign policy and war on terrorism. This usage is directly related to power. Both explicit and implicit threats are used in the interviews. Examples of threat are found with reference to Iran, Syria, North Korea, Egypt, and Russia. However, it has been observed that with reference to Iran, Syria, and North Korea threat is explicit whereas it is implicit with reference to Egypt and Russia. The following two examples illustrate the use of threat by Clinton:

Explicit threat with reference to Iran:

Clinton: But this is an unacceptable, uh, path that they must, uh, stop or, uh, action will have to be taken.

Implicit threat with reference to Russia:

Clinton: We can take our aid money and go elsewhere and help people who welcome us.

Thus, it can be noted that power is manifested in Clinton's discourse in more than one way. First, she uses language strategically through manipulating transitivity, modality, and personal pronouns. Second, she uses rhetorical persuasion in her discourse which allows her to persuade her audiences of what she says. Third, she uses some linguistic mechanisms that are directly related to power. All these features can be grouped under power in discourse which is identified by Fairclough and Wodak (1997) as a way of expressing power.

Another type of power which, according to Fairclough and Wodak (1997), is known as power over discourse, is evident in the interviews. This type of power appears in the way in which Clinton controls and changes the structure of the order of discourse when she uses novel combinations of existing discourses such as combining political discourse with ordinary life. It is also evident in her response to some questions not as demanding an answer but as an invitation for delivering a political speech. In this way, she becomes able to express many of her views about issues she is concerned with such as women rights, war in Iraq, and economy. The following example illustrates this usage in which she expresses her views about specific issues when talking about America's foreign policy

Clinton: ...We've been subject over the last 30 or 40 years to a lot of actions taken by the United States from the Vietnam War to the War in Iraq that have had unintended consequences that have threatened us. We want to be more thoughtful and careful about the interventions we make. And finally, don't lose the trend lines. While we are focused on the immediate crisis and the longer term challenges, there are a lot of 
forces at work in the world, whether it is the changes in technology which has such profound effect on how we exercise all forms of our power. Whether it is women and girls, the roles and rights that they have, and the fact that where they do have equality and dignity, you're likely to have more stable societies and more prosperous economies.

\subsection{The use of Ideology}

The analysis shows the various political and ideological positions taken by Clinton. For example, readings about Clinton's views show that she is a strong supporter of Israel and that she makes strong statements in the past approving of the construction of the barrier fence between Israel and the West Bank. In NY senate debate 2000, She states that she is "an emphatic, unwavering supporter of Israel's safety and security"(Issues, 2000, p. 1). These views are quite evident in the interviews. They are expressed both implicitly and explicitly. Similarly, a close analysis of the interviews reveals her views about the Iraq war and women's rights. This means that Clinton's discourse is subject to ideological interpretation. In the interviews analyzed, ideology is expressed through different analytical categories. These analytical categories are in line with van Dijk's (2011) categories of ideological analysis. They include lexicalization, implication, authority, evidentiality, example/illustration, distancing, polarization, national self-glorification, and consensus. The following sub sections will discuss each of these categories in detail.

\subsubsection{Lexicalization}

Because similar meanings can be expressed in different words, Clinton's choice of lexical items to represent her points of views, concepts and beliefs may not be regarded as neutral. Thus, Clinton's use of negative expressions denoting Iran, North Korea, Hamas, and Hezbollah and their actions, on the one hand, and her use of positive expressions denoting US, and American Administration and their actions, on the other hand, may be viewed as strategic.

\subsubsection{Implication}

The analysis of the data shows that Clinton's way of designing her discourse is ideological. To illustrate, Clinton refers to Iran using expressions such as "the terrorism aspect of Iran's behavior" and "their terrorism". Moreover, she uses the verb "claim" instead for example of "say" or "indicate". This usage implies a specific image about Iran that Clinton wants her hearers to perceive.

\subsubsection{Authority}

The interviews analyzed also contain frequent references to president Obama, what he has said, and his views in addition to direct quotations for his speech. This usage can be interpreted ideologically as a means of granting acceptance of what Clinton says. The following example illustrates this ideological usage when talking about the Syrian regime.

Clinton: ..., and the president mentioned that in his speech today.... And part of what the President - our president - Obama was doing today, was to say ...

\subsubsection{Evidentiality}

Evidentiality is employed strategically in the interviews in order to make Clinton's points of view more plausible. This category is seen in Clinton's presentation of evidences and/or proofs for her opinions. In the following example, Clinton refers to the accountability review board to support her stance when she was asked about whether she regretted saying "what difference at this point does it make?"

Clinton: ... The accountability review board, chaired by Ambassador [Thomas] Pickering and Admiral [Michael] Mullen didn't pay any attention to that.

\subsubsection{Example/ Illustration}

The analysis of the data shows that Clinton's use of concrete examples in the interviews can also be interpreted ideologically. This use is intended to make her discourse more "lively" and to imply her democratic values. Moreover, it can be seen as part of populist strategies. In the following example, Clinton gives a concrete example to defend and illustrate her point of view about "the terrorism aspect of Iran" and to provide impelling forms of empirical proof.

Clinton: ... you know, when we found out about the plot to kill the, uh, ambassador from Saudi Arabia-..., there was disbelief on the part of a lot of countries 


\subsubsection{Distancing}

In the interviews analyzed, Clinton uses words that imply distance between in-group speakers and out-group ones. This device is expressed by the use of demonstrative pronouns instead of naming or describing the others. Examples of such usage are "these guys need to be stopped", "these governments", and "Nobody is satisfied with what these two countries are attempting to do".

\subsubsection{Polarization}

Clinton's discourse in the interviews may be interpreted as monitored by underlying social representations in which attitudes and ideologies of groups are polarized. This polarization, i., e., "us" vs. "them", is clear with reference to Clinton's discourse on foreign policy. It is expressed through various analytical categories including actor description, categorization, positive self-presentation and negative other-presentation.

First, it has been noted that the choice of how people are described is strategic. So, Clinton's description of them as individuals or as members of groups, by their actions or attributes, or by their positions and relations to other people may be interpreted ideologically. In the interviews analyzed, descriptions of others or out-groups is found to convey negative opinions about them. This finding, according to van Dijk (2011), indicates that descriptions are never neutral and that they have semantic, rhetorical and argumentative functions in the expression of opinions and standpoints.

Second, the analysis shows that Clinton categorized "in-groups" and "out-groups" people in a way that attributes them positive or negative characteristics. Typical of this categorization in the interviews is subcategorizing Iranians as "terrorists" and Americans as fulfilling the idea of "our founders of equality under the law and a nation that was really built on fundamental freedoms".

This categorization of people in in-groups and out-groups and the division of them into good and bad is emphasized by positive self-presentation and negative other-presentation in the interviews. So, there appears a difference in the presentation of Iran, North Korea, Syria, Russia, Hamas, and Hezbollah, on the one hand, and Israel and US, on the other hand. This positive self-presentation and negative other-presentation is emphasized through the use of comparison, contrast and repetition.

\subsubsection{National self-glorification}

The analysis of the data shows that the use of positive self-presentation is implemented by various forms of national self-glorification. So, Clinton's discourse is characterized by positive references to her own country, its principles, history and traditions. This finding is in line with Unvar and Rahimi (2013) who observe that this ideology is employed in Obama's speech. The following example illustrates this usage in Clinton's discourse about US foreign policy.

Clinton: Re-assert leadership politically and economically... so that yes, America will and must lead, it is the indispensible nation

\subsubsection{Consensus}

Clinton uses consensus in the interviews analyzed. She combines her views and opinions with nationalist ones so that the unity and the interests of the nation are placed before any other thing. This category is exemplified in Clinton's saying "the obligation we all have as public servants" and "to keep our people safe".

This finding regarding the use of analytical categories is similar to that of Rashidi and Souzandehfar (2010) who note that Clinton uses subtle ideological structures in her speech to justify her claims. Among these ideological structures which, according to them, Clinton used frequently are positive self-presentation and negative other-presentation, lexicalization, and polarization. The results are also in line with those of Unvar and Rahimi (2013) who remark that Obama's speech is ideologically structured through the use of national self-glorification, consensus, and polarization.

\section{Conclusion}

The present study investigates American interview genre as exemplified in TV interviews with the former Secretary of State Hillary Clinton. The study adopts a critical discourse analysis approach that draws on genre theory, CDA, and systemic functional grammar. Results of the study showed that American interview genre is characterized by "hyperidity" or "intertextuality" which is considered a feature of interviews in modern society. It combines features of two genres of spoken discourse, namely, interview and conversation. Moreover, it combines elements of political discourse with elements of personal and ordinary life and experience. Results also showed that Clinton's discourse is dependant on the use of long compound and complex sentences rather than short and simple ones. They also showed 
that her use of language is strategic. She applies rhetorical strategies of persuasion such as rhetorical questions, listing, contrastive devices, and extreme case formulations. In addition, she used specific linguistic devices to achieve power in discourse and power over discourse. Power in discourse is shown in Clinton's strategic use of transitivity, personal pronouns, and modality, her comments on the interviewers' questions, and her use of rhetorical persuasion. Power over discourse, on the other hand, appears in Clinton's use of certain linguistic mechanisms that include long turn taking and threat. Finally, results indicated that Clinton's discourse is employed ideologically through the use of various analytical categories. These categories illustrate the ideological based properties of Clinton's discourse structure and reveal her political positions and views towards specific issues both explicitly and implicitly.

However, there appear two limitations in the study. The number of the TV interviews analyzed is small. Second, the TV interviews analyzed have been done in America and directed to American people.

\section{1 Suggestions for future research}

The present study focuses on American interview genre as represented in Clinton's discourse. More investigations can be conducted on Clinton's political discourse. Similar investigations can be conducted on the discourse of other American figures. Moreover, American-British comparative studies can be applied to interview genre to find out similarities and differences.

\section{References}

Aisyah, S. S. (2012). Expression of modality and evaluation in Hillary Clinton's speech. MA thesis. Retrieved May 8, 2014 from http://a-research.upi.edu

Bhatia, V. K. (2002). Applied genre analysis: A multi-perspective model. Retrieved March 15, 2012, from http://www.aelfe.org

Biber, D., Johanasson, S., Leech, G., Conrad, S., \& Finegan, E. (1999). Longman grammar of spoken and written English. Harlow: Longman.

Brody, H. (1992). The healer's power. New Heaven: Yale University Press.

Cap, P. \& Okulska, U. (Eds.). (2013). Analysing genres in political communication. Amsterdam: John Benjamins Publishing Company. http://dx.doi.org/10.1075/dapsac.50

Chouliaraki, L., \& Fairclough, N. (1999). Discourse in late modernity: Rethinking critical discourse analysis. Edinburgh: Edinburgh University Press.

Fairclough, N. (1989). Language and power. London: Longman.

Fairclough, N. (1992). Discourse and text: Linguistics and intertextual analysis within discourse analysis. Discourse and Society, 3(2), 193-217. http://dx.doi.org/10.1177/0957926592003002004

Fairclough, N. (1995a). Media discourse. London: Edward Arnold.

Fairclough, N. (1995b). Critical discourse analysis. London: Longman.

Fairclough, N. (2003). Analyzing discourse: Textual analysis for social research. London: Routledge.

Fairclough, N., \& Wodak, R. (1997). Critical discourse analysis. In T. A. van Dijk (Ed.), Discourse Studies: A multidisciplinary introduction (vol. 2, pp. 258-284). London: Sage Publications.

Fisker, S. L. M. (2009). Power in discourse: A Critical discourse analysis of the concluding democratic presidential $\begin{array}{llllll}\text { debates } 2008 . & \text { Retrieved } & \text { April } & \text { 2014, } & \text { from }\end{array}$ http://projekter.aau.dk/projekter/files/18011253/2009-08-03_10.29.28.pdf

Halliday, M. A. K. (1978). Language as social semiotic. London: Edward Arnold.

Halliday, M. A. K. (1985). Introduction to functional grammar. London: Edward Arnold.

Halliday, M. A. K., \& Matthiessen, C. (2004). An introduction to functional grammar (3 ${ }^{\text {rd }}$ ed.). London: Longman.

Henderson, R. (2005). A Faircloughian approach to CDA: Principled eclecticism or a method searching for a theory? Melbourne Studies in Education, 46 (2), 9-24. http://dx.doi.org/10.1080/17508480509556422

Horvath, J. (2009). Critical discourse analysis of Obama's political discourse. Retrieved February 10, 2013, from http://www1.cs.columbia.edu

Hutchby, I., \& Wooffitt, R. (1998). Conversation analysis: Principles, practices and applications. Cambridge: Polity Press. 
Klanicová, E. (2013). Genre analysis of TV interview based on gender differences. Master's diploma thesis. Retrieved April 10, 2013, from http://is.muni.cz/th/210318/ff_m/DT_final_version.pdf

Kress, G. (1990). Critical discourse analysis. Annual Review of Applied Linguistics, 11, 84-99. http://dx.doi.org/10.1017/S0267190500001975

Lazio, R. (2000, October 28). Rick Lazio on foreign policy. Issues. Retrieved January10, 2013, from http://www.ontheissues.org

Leeuwen, T. V. (2009). Critical discourse analysis. In J. Renkema (Ed.), Discourse of course: An overview of discourse studies (pp. 277-292). Amsterdam: John Benjamins Publishing Company. http://dx.doi.org/10.1075/z.148.27lee

Melamede, V. (1999). Hillary Clinton: Strategies and goals. Retrieved March 15, 2014, from http://debate.uvm.edu/impeachment/melamede.html

Myhill, J. (1995). Change and continuity in the function of American English modals. Linguistics, (33), 157-211.

Paltridge, B. (2013). Critical Discourse analysis. In K. Hyland (Ed.), Discourse studies reader: Essential excerpts (pp. 89-109). London: Bloomsbury Academic.

Rashidi, N., \& Souzandehfar, M. (2010). A critical discourse analysis of the debates between republicans and democrats over the continuation of war in Iraq. Retrieved 10, May, from http://www.uab.ro/jolie/2010/4_rashidi-souzandehfar.pdf

Shayegh, K., \& Nabifar, N. (2012). Power in political discourse of Barak Obama. Journal of Basic and Applied Scientific Research, 2(4) 3481-3491.

Stubbs, M. (1997). Whorf's children: Critical comments on CDA. In A. Ryan, \& A. Wray (Eds.), Evolving models of language. Milton Keynes: Multilingual Matters. Retrieved January 10, 2014, from http:/www.uni-trier.de/fileadmin/fb2/ANG/Linguistik/Stubbs/stubbs-1997-whorfs-children.pdf

Tannen, D. (1993). The relativity of linguistic strategies: Rethinking power and solidarity in genderand dominance. In D. Tannen (Ed.), Gender and conversational interaction (pp. 165-188). New York: Oxford University Press.

Tracy, K., Inez-Guillem, S. M., Robles, J. S., \& C'asteline, K. E. (2011). Critical discourse analysis and US communication scholarship. In C. T. Salmon (Ed.), Communication Yearbook (vol.3, pp. 241-186). New York: Routledge.

Thornbury, S., \& Slade, D. (2006). Conversation: From description to pedagogy. Cambridge: Cambridge University Press. http://dx.doi.org/10.1017/CBO9780511733123

Unvar, S., \& Rahimi, A. (2013). A critical discourse analysis of discursive structures in a political text. International Journal of Science and Advanced Technology, 3 (3), 12-20.

van Dijk, T. A. (1988). News as discourse. New Jersey: Lawrence Erlbaum Associates.

van Dijk, T. A. (1993). Principles of critical discourse analysis. Discourse and Society, 4 (2), 249-283. http://dx.doi.org/10.1177/0957926593004002006

van Dijk, T. A. (1997). What is political discourse analysis? Retrieved January 20, 2013, from http://www.discourses.org

van Dijk, T. A. (2011). Ideology and discourse. A multidisciplinary introduction. http://dx.doi.org/10.4135/9781446289068.n18

Wang, J. (2010). A critical discourse analysis of Barak Obama's speeches. Journal of Language Teaching and Research, 1(39) 254-261. http://dx.doi.org/10.4304/jltr.1.3.254-261

West, C. \& Zimmerman, D. H. (1985). Gender, language, and discourse. In T. A. van Dijk (Ed.), Handbook of discourse analysis (vol. 4, pp. 103-124). London: Academic Press.

Wodak, R. (2011). The discourse of politics in action: Politics as usual. New York: Palgrave Macmillan. http://dx.doi.org/10.1057/9780230316539

Wodak, R., \& Meyer, M. (Eds.). (2009). Methods of critical discourse analysis (2 ${ }^{\text {nd }}$ ed.). London: Sage Publications Ltd.

Zupnik, J. Y. (1991). Norman Fairclough: Language and power. Language in Society, 20, 265-269. http://dx.doi.org/10.1017/S0047404500016316 